\title{
In vitro anthelmintic activity of leaf extracts of four different types of calamus species
}

\begin{abstract}
Development of anthelmintic resistance and high cost of conventional anthelmintic drugs led to the evaluation of medicinal plants as an alternative source of anthelmintics. In the present study, methanol, ethanol and chloroform leaf extract of Calamus guruba, Calamus viminalis, Calamus erectus and Calamus tenuis were explored for anthelmintic activity at two concentrations $(50$ and $100 \mathrm{mg} / \mathrm{ml})$, using adult earth worm Pheretima posthuma. All the leaf extracts of Calamus species tested for the anthelmintic activity possess significant activity in a dose dependent manner as compared to the albendazole. The overall findings of the present study have shown that Calamus guruba, Calamus viminalis, Calamus erectus and Calamus tenuis contain possible anthelmintic compounds.
\end{abstract}

Keywords: Calamus guruba, Calamus viminalis, Calamus erectus, Calamus tenuis, Anthelmintic activity, Pheretima Posthuma, Albendazole, In vitro study, hookworm infestation, entrobiasis, filariasis, taeniasis; hydatidcyst, fluke infection, helminthiasis, wonder drug, niclosamide, oxyclozanide, bithionol

Volume 5 Issue 2 - 2017

\author{
Sajan Das, Rumana Akhter, Sumaiya Huque, \\ Rafi Anwar, Promit Das, Kaniz Afroz Tanni \\ and Mohammad Shahriar
}

Department of Pharmacy, University of Asia Pacific, Bangladesh

\begin{abstract}
Correspondence: Mohammad Shahriar, Department of Pharmacy, University of Asia Pacific, Bangladesh, Tel +881841844259, Email shahriar@uap-bd.edu
\end{abstract}

Received: January 30, 2017 | Published: April 17, 2017

\section{Introduction}

Infections caused by various species of parasitic worms (helminths) of the gastrointestinal tract are the most widespread of all chronic infections of humans in developing countries including Bangladesh and produce a global burden of disease that exceeds better-known conditions, including malaria and tuberculosis. ${ }^{1}$ It is estimated that approximately one-third of approximately three billion people that live on less than two US dollars per day in developing regions of sub-Saharan Africa, Asia, and the Americas are infected with one or more helminth. ${ }^{2,3}$ The common helminthic infections in Bangladesh are ascaiasis, hookworm infestation, entrobiasis, filariasis, taeniasis, hydatidcyst and fluke infection (liver, blood, intestinal tract). The current antihelminthic therapies act by incapacitating the parasite by paralysis, damaging the worm such that the immune system can eliminate it, or by altering its metabolic processes. Because the metabolic requirements of these parasites vary greatly from one species to another, drugs that are highly effective against one type of worm are ineffective against others and because of the prevalence of helminth infections, treatment of helminthiasis is of practical therapeutic importance although the synthetic drugs used in helminthiasis treatment have some potential side effects. ${ }^{4}$ The present experimental work was designed for the search of anthelmintic activity of medicinal plants. Extracts of four medicinal plants of Arecaceae family were conducted in this study. Calamus guruba is well known in Bangladesh as chikan bet or jali bet. The fruit's of $C$. guruba are the most commonly used parts of this plantand are widely used in traditional medicine and food. The fruit is traditionally known as a tranquilizer and a general "wonder drug." It is a sedative, hypotensive, muscle relaxant as well as its used to cure cough, cold, pulmonary disorders. In addition, the fruit extract have demonstrated some enzymatic antioxidant activities. Study on the nutritional composition of the fruits of C. guruba demonstrated the presence of total $(1.73 \%)$ sugar, $(1.15 \%)$ protein, $(6.45 \%)$ carbohydrates and $(72.39 \%)$ moisture content. ${ }^{5}$ Biological study of this plant is yet to be conducted. Calamus viminalis is known as Khorkoijja bet in Bangladesh and is widely used as handicrafts and furniture material. Ripe fruit pulps are edible. This plant has also been used in traditional medicine for treatment of dog bite, urogenital and gynecological infection. ${ }^{6}$ The leaf extract of $C$. viminalis demonstrated to have gastrointestinal motility, antipyretic activity, anti-nociceptive activity and Neurophramacological activity with no potential acute toxicity. ${ }^{6}$ Calamus erectus is used for making huts and poultry houses. The seeds of this plant are widely used as chewable food. Antihyperglycemic effect of methanol extract was found to be more effective. ${ }^{7}$ Very few extensive biological studies have been carried out on this plant. Calamus tenuis Roxb is used for making high quality handicrafts. The cultivation of this species for the production of edible shoots is becoming increasingly widespread in Lao PDR, and also North-east Thailand as the shoot is edible. Phytochemical screening of the fruits of $C$. tenuis reveals the presence of alkaloid, tannin, flavonoid, and steroid which may be responsible to have antioxidant and cytotoxic potential. ${ }^{8}$ The leaf extract of $C$. tenuis demonstrated to have gastrointestinal motility, antipyretic activity, anti-nociceptive activity, Neurophramacological activity and anti-diarrheal activity. ${ }^{9}$ The present study was performed for the first time and the objective of this study was to determine the in vitro anthelmintic activity of methanol, ethanol and chloroform leaf extracts of C. guruba, C. viminalis, C. erectus \& C. tenuis.

\section{Materials and methods \\ Collection, identification and processing of plant samples}

Fresh leaves of $C$. guruba, C. viminalis, C. erectus \& C. tenuis were collected from Botanical Garden, Mirpur-1, Dhaka in November 2015 and all the four plant samples were taxnomically identified with the help of the National Herbarium of Bangladesh, Mirpur-1, Dhaka, where each voucher specimen was deposited. These plants were referenced under the following number: 42754/ DACB, 42755/ DACB, 42756/ DACB and 42757/ DACB respectively for $C$. 
guruba, C. viminalis, C. erectus \& C. tenuis. The leaves were washed thoroughly 2-3times with running tap water and were sun dried for seven days in order to remove the moisture contents and then ground into coarse powder using high capacity grinding machine (Jaipan designer mixer grinder, jaipan, India) which was then stored in airtight container with necessary markings for identification and kept in cool, dark and dry place for the investigation.

\section{Extraction procedure}

The powdered plant parts (30gm) were successively extracted in a soxhlet extractor at elevated temperature $(40-60)^{\circ} \mathrm{C}$ using $300 \mathrm{ml}$ of distilled methanol followed by ethanol, and chloroform. After extraction, all extracts were kept in refrigerator at $4^{\circ} \mathrm{C}$ for future investigations with their necessary markings for identification.

\section{Experimental animal}

For the experiment, earthworms were collected from moist soil, near the area of The Board of Intermediate and Secondary Education, Comilla and washed with normal saline to remove soil and fecal matter during the experiment. The earthworms of $5-7 \mathrm{~cm}$ length and $0.2-0.3 \mathrm{~cm}$ width were used for the experimental protocol.

\section{Preliminary phytochemical screening}

Different extracts were subjected to preliminary phytochemical screenings to determine the nature of phytoconstituents by using standard protocols. ${ }^{10}$

\section{Anthelmintic activity}

The anthelmintic assay was carried as per the method of Ajaiyeoba et al. ${ }^{11}$ with minor modifications. In this experiment, Pheretima posthuma were used because of its anatomical and physiological similarity with intestinal roundworm parasites of human beings and they for the fact that they belong to same group of Annelida. All the test solutions and standard drug solutions were prepared freshly before starting the experiment. Albendazole $(10 \mathrm{mg} / \mathrm{ml})$ was used as reference standard while saline water served as a control. One hundred and fifty six earthworms were divided into twenty six groups with equal size \& each group containing six worms. $60 \mathrm{ml}$ formulations containing two different concentrations of methanol, ethanol and chloroform extracts of $C$. guruba, $C$. viminalis, C. erectus \& C. tenuis leaves $(50$ and $100 \mathrm{mg} / \mathrm{ml}$ in distilled water) were prepared. The time for paralysis (in min) was noted when no movement of any sort could be observed except when the worms were shaken vigorously. The time of death of the worms (in min) was recorded after ascertaining that worms neither moved when shaken vigorously or when dipped in warm water $\left(50^{\circ} \mathrm{C}\right)$.

\section{Statistical analysis}

All the data are expressed as Mean \pm SEM (Standard error of Mean).The results were analyzed statistically by ANOVA followed by Dunnet's test. Results below ${ }^{*} p<0.05,{ }^{* *} p<0.01$ and ${ }^{* * *} p<0.001$ are considered statistically significant.

\section{Results and discussion}

Table 1 represents the results of the phytochemical screenings of the leaf extracts of of $C$. tenius, $C$. viminalis, $C$. guruba, and $C$. erectus.

In vitro anthelmintic activity was conducted with methanol, ethanol and chloroform leaf extracts of $C$. guruba, C. viminalis, $C$. erectus \& C. tenuis at the doses of $50 \mathrm{mg} / \mathrm{ml}$ and $100 \mathrm{mg} / \mathrm{ml}$. The result of the anthelmintic activity of methanolic leaf extracts of C. guruba, C. viminalis, C. erectus \& C. tenuis as well as reference drug are presented in Figure $1 \&$ Table 2. The methanolic leaf extracts of $C$. viminalis, C. erectus \& C. tenuis demonstrated death of worms in less time as compared to albendazole especially at higher concentration of $100 \mathrm{mg} / \mathrm{ml}$. Methanolic extracts of selected Calamaus species produce dose dependent paralysis ranging from loss of motility to loss of response to external stimuli in a significant manner $(* * \mathrm{p}<0.01$; $* * * p<0.001)$ which gradually lead to death. Among the four selected plant methanol extract of $C$. tenuis produce a significant decrease in paralysis time $(* * \mathrm{p}<0.01)$ and death time $(* * * \mathrm{p}<0.001)$ as compared to the standard albendazole.

Table I Phytochemical screening for the leaf extracts of $C$. tenius, $C$. viminalis, $C$. guruba, and $C$. erectus

$[(+)$ : Presence, $(++)$ : Strong presence, (-):Absence $]$
C. Tenius
C. Viminalis
C. Erectus
C. Guruba

Name Of The Test(S)

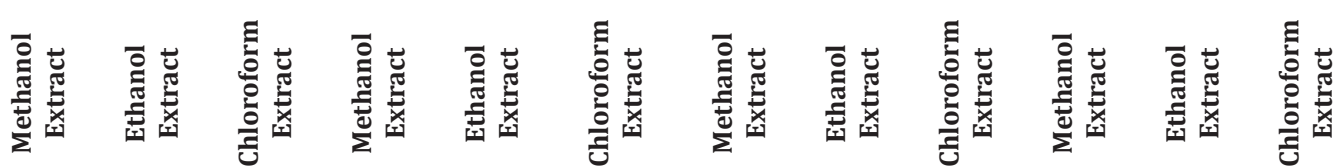

\begin{tabular}{|c|c|c|c|c|c|c|c|c|c|c|c|c|c|}
\hline & Hager's test & + & + & - & + & + & - & + & + & - & ++ & + & - \\
\hline \multirow{2}{*}{ Alkaloid } & Mayer's test & ++ & + & - & + & ++ & - & + & - & - & + & - & - \\
\hline & Wagner's test & ++ & ++ & - & + & + & - & + & + & - & - & - & - \\
\hline \multirow{2}{*}{ Carbohydrate } & Molisch's test & - & + & - & - & + & + & + & ++ & - & - & + & - \\
\hline & Fehling's test & ++ & - & + & - & + & + & - & + & - & - & + & - \\
\hline
\end{tabular}


Table Continued.

\begin{tabular}{|c|c|c|c|c|c|c|c|c|c|c|c|c|c|}
\hline \multirow{2}{*}{\multicolumn{2}{|c|}{ Name of The Test(S) }} & \multicolumn{3}{|c|}{ C. Tenius } & \multicolumn{3}{|c|}{ C. Viminalis } & \multicolumn{3}{|c|}{ C. Erectus } & \multicolumn{3}{|c|}{ C. Guruba } \\
\hline & & 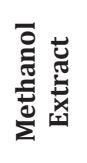 & 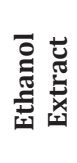 & 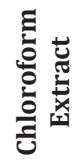 & 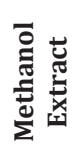 & 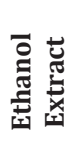 & 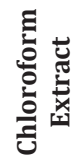 & 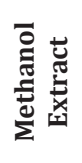 & 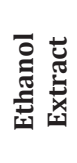 & 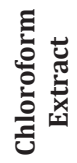 & 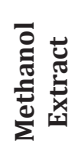 & 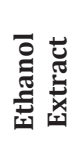 & 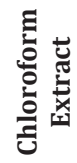 \\
\hline \multirow{2}{*}{ Flavonoid } & $\begin{array}{c}\text { Lead acetate } \\
\text { test }\end{array}$ & - & + & - & ++ & + & - & ++ & ++ & - & + & + & - \\
\hline & $\begin{array}{c}\text { Ferric chloride } \\
\text { test }\end{array}$ & + & + & - & ++ & - & - & ++ & + & - & + & + & - \\
\hline Steroid & $\begin{array}{c}\text { Libermann } \\
\text { Burchard's Test }\end{array}$ & - & + & - & ++ & - & - & + & ++ & - & ++ & - & + \\
\hline Saponin & Froth Test & + & + & + & - & ++ & ++ & ++ & - & - & ++ & ++ & + \\
\hline Phenol & $\begin{array}{c}\text { Ferric chloride } \\
\text { test }\end{array}$ & + & + & + & + & + & - & + & ++ & - & + & + & + \\
\hline Tannin & & + & + & - & + & + & - & + & ++ & + & + & ++ & - \\
\hline Glycoside & & + & + & - & ++ & + & - & - & + & - & ++ & - & - \\
\hline Fixed oil & & ++ & ++ & - & - & + & + & + & - & + & + & + & - \\
\hline
\end{tabular}

Table 2 Comparative statistical variance of analysis (ANOVA) on anthelmintic activity of methanol extract (leaf) of $C$. guruba, C. viminalis, C. erectus \& C. tenuis

\begin{tabular}{lllllll}
\hline & & SS & df & MS & F & $P$ \\
\hline \multirow{2}{*}{ Paralysis Time } & Between & 7145.926 & 8 & 893.241 & 106.338 & 0.000 \\
& Within & 378 & 45 & 8.4 & & \\
& Total & 7523.926 & 53 & & & \\
Death Time & Between & 8729.815 & 8 & 1091.227 & 84.0363 & 0.000 \\
& Within & 584.333 & 45 & 12.985 & & \\
& Total & 9314.148 & 53 & & &
\end{tabular}

*SS, sum of squares; df, degree of freedom; MS, mean square; $F$, fisher value; P, probability value 0.05 . Each value represents mean $\pm S E M(N=6)$. Data are found to be significant by testing through one way ANOVA with replication at $1 \%$ level of significance

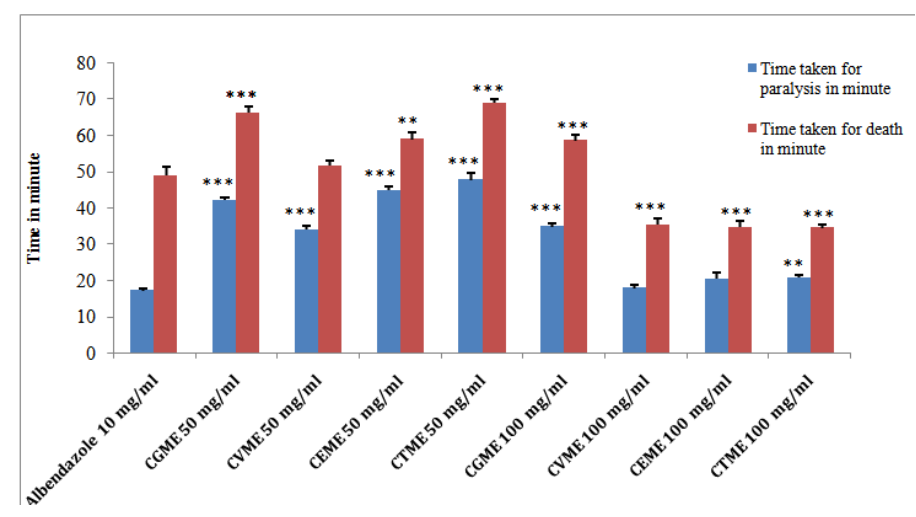

Figure I Anthelmintic activity of methanol extract (leaf) of C. guruba, C. viminalis, $C$. erectus and C. tenuis.

(Methanol extract of Calamus guruba: CGME, Methanol extract of Calamus viminalis: CVME, Methanol extract of Calamus erectus: CEME, Methanol extract of Calamus tenuis: CTME) (Values are expressed as mean \pm S.E.M. $(\mathrm{n}=6), * * p<0.01, * * * p<0.001$ significant when compared with the corresponding value of the Standard group, done by independent sample test).
The result of the anthelmintic activity of ethanol extracts of $C$. guruba, C. viminalis, C. erectus \& C. tenuis leaf as well as reference drug are presented in Figure $2 \&$ Table 3. The present study with $C$. guruba, C. viminalis, C. erectus \& C. tenuis leaf revealed that ethanol extract $(50$ and $100 \mathrm{mg} / \mathrm{ml})$ caused paralysis as well as death of worms in a significant dose dependent manner $\left({ }^{*} p<0.05 ;{ }^{* *} p<0.01\right.$; $* * * p<0.001$ ). When compared with the activity of ethanol extract of C. guruba, C. erectus \& C. tenuis the activity of the ethanol extract of $C$. viminalis at $100 \mathrm{mg} / \mathrm{ml}$ showed significantly less time to cause death $(* * * p<0.001)$ which is even lower than the standard drug.

(Ethanol extract of Calamus guruba: CGEE, Ethanol extract of Calamus viminalis: CVEE, Ethanol extract of Calamus erectus: CEEE, Ethanol extract of Calamus tenuis: CTEE) (Values are expressed as mean \pm S.E.M. $(\mathrm{n}=6), * p<0.05, * * p<0.01, * * * p<0.001$ significant when compared with the corresponding value of the Standard group, done by independent sample test).

After investigation of chloroform extracts of C. guruba, C. viminalis, C. erectus \& C. tenuis leaf, following data were observed (Figure 3) (Table 4), where the higher concentration of chloroform extract $(100 \mathrm{mg} / \mathrm{ml})$ showed significant $\left({ }^{*} p<0.05 ;{ }^{* *} p<0.01 ; * * * p<0.001\right)$ decrease in paralysis and death time. Among the chloroform extracts 
of all plants, the present study revealed the anthelmintic activity of C. tenius was higher as compared to others, although, the chloroform extract of C. guruba, C. viminalis, C. erectus \& C. tenuis leaf (50 and $100 \mathrm{mg} / \mathrm{ml}$ ) caused paralysis as well as death of worms in a significant dose dependent manner $\left({ }^{*} p<0.05 ; * * p<0.01 ; * * * p<0.001\right)$.

Table 3 Comparative statistical variance of analysis (ANOVA) on anthelmintic activity of ethanol extract (leaf) of $C$. guruba, $C$. viminalis, $C$. erectus \& $C$. tenuis

\begin{tabular}{lllllll}
\hline & & SS & df & MS & F & $P$ \\
\hline & Between & 10381.333 & 8 & 1297.667 & 31.725 & 0.000 \\
$\begin{array}{lllllll}\text { Paralysis } \\
\text { Time }\end{array}$ & Within & 1840.667 & 45 & 40.904 & & \\
& Total & 12222 & 53 & & & \\
& Between & 13669.703 & 8 & 1708.713 & 79.929 & 0.000 \\
& & & & & & \\
$\begin{array}{l}\text { Death } \\
\text { Time }\end{array}$ & Within & 962 & 45 & 21.378 & & \\
& & & & & & \\
& Total & 14631.703 & 53 & & & \\
\hline
\end{tabular}

*SS, sum of squares; df, degree of freedom; MS, mean square; F, fisher value; $P$, probability value 0.05 . Each value represents mean \pm SEM $(N=6)$. Data are found to be significant by testing through one way ANOVA with replication at I\% level of significance

Table 4 Comparative statistical variance of analysis (ANOVA) on anthelmintic activity of chloroform extract (leaf) of C. guruba, C. viminalis, C. erectus \& $C$. tenuis

\begin{tabular}{lllllll}
\hline & & SS & df & MS & F & P \\
\hline & Between & 6147.148 & 8 & 768.394 & 44.264 & 0.000 \\
$\begin{array}{l}\text { Paralysis } \\
\text { Time }\end{array}$ & Within & 781.167 & 45 & 17.359 & & \\
& Total & 6928.315 & 53 & & & \\
& Between & 9065.667 & 8 & 1133.208 & 63.970 & 0.000 \\
Death & Within & 797.167 & 45 & 17.715 & & \\
Time & Total & 9862.834 & 53 & & & \\
& & & & & & \\
\hline
\end{tabular}

*SS, sum of squares; $\mathrm{df}$, degree of freedom; MS, mean square; F, fisher value; $P$, probability value 0.05 . Each value represents mean \pm SEM $(N=6)$. Data are found to be significant by testing through one way ANOVA with replication at $1 \%$ level of significance.

(Chloroform extract of Calamus guruba: CGChE, Chloroform extract of Calamus viminalis: CVChE, Chloroform extract of Calamus erectus: CEChE, Chloroform extract of Calamus tenuis: CTChE) (Values are expressed as mean \pm S.E.M. $(\mathrm{n}=6), * p<0.05, * * p<0.01$, $* * * p<0.001$ significant when compared with the corresponding value of the Standard group, done by independent sample test).

The use of natural dietary compounds has the potential to be a complementary control option which may reduce this reliance on drug treatment, and slow the development of resistance parasites. In this study, anthelmintic assay of various extracts of $C$. guruba, C. viminalis, $C$. erectus \& C. tenuis was performed on adult Bangladeshi earthworms, Pheretima posthuma due to its anatomical and physiological similarity with intestinal roundworm parasites of human beings as well as their ease of availability and have been used widely for the initial evaluation of anthelmintic compounds in vitro. The result of the present study indicates that all the three leaf extracts of Calamus species tested for the anthelmintic activity possess significant activity as compared to the albendazole, which is a broad spectrum anthelmintic. Albendazole acts by inhibiting microtubules polymerization after binding to the colchicine sensitive site of $\beta$-tubulin. Which causes decrease in microtubules in the intestinal cells, absorptive function, and uptake of glucose by the adult and larval forms of the parasites thereby depletes glycogen storage. Paralysis and death of susceptible GI parasites occur slowly due to insufficient energy for the production of adenosine trisphosphate and their clearance from the GI tract may not be complete until several days after treatment. ${ }^{4}$ In addition to its vermicidal properties, it has been found to have both ovicidal and larvicidal activities in human. The use of natural plant extracts as de-wormers for humans and livestock has long been practiced, however scientific validation of these practices and identification of active compounds has been lacking. ${ }^{12-14}$ Anthelmintic effects of plants are normally ascribed to secondary metabolites such as essential oils, ${ }^{15}$ flavonoids, alkaloids, terpenoids ${ }^{16}$ or polyphenols such as proanthocyanidins, ${ }^{17}$ also known as condensed tannins. Tannins are non-nitrogenous plant constituents and have an astringent action on mucous membranes as they precipitate protein from the cells of mucous membranes and exert a protective action. Some synthetic phenolic anthelmintics e.g. niclosamide, oxyclozanide, bithionol etc., are reported to interfere with energy generation in helminth parasites by uncoupling oxidative phosphorylation. ${ }^{18}$ Moreover, direct anthelmintic effects of purified condensed tannins have been confirmed in in vitro assays against, amongst others, Haemonchus contortus ${ }^{19}$ Ostertagia ostertagi ${ }^{20}$ and Ascaris suum ${ }^{21}$ as tannins can bind to free proteins in the gastrointestinal tract of host animal or glycoprotein on the cuticle of the parasite and cause death. ${ }^{4,22}$ Tannin containing plants increase the supply and absorption of digestible protein by animals. ${ }^{23}$ This is achieved by the formation of protein complexes in the rumen by tannins, which later dissociate at low $\mathrm{pH}$ in the abomasum to release more protein for metabolism in the small intestines of ruminant animals. ${ }^{24}$

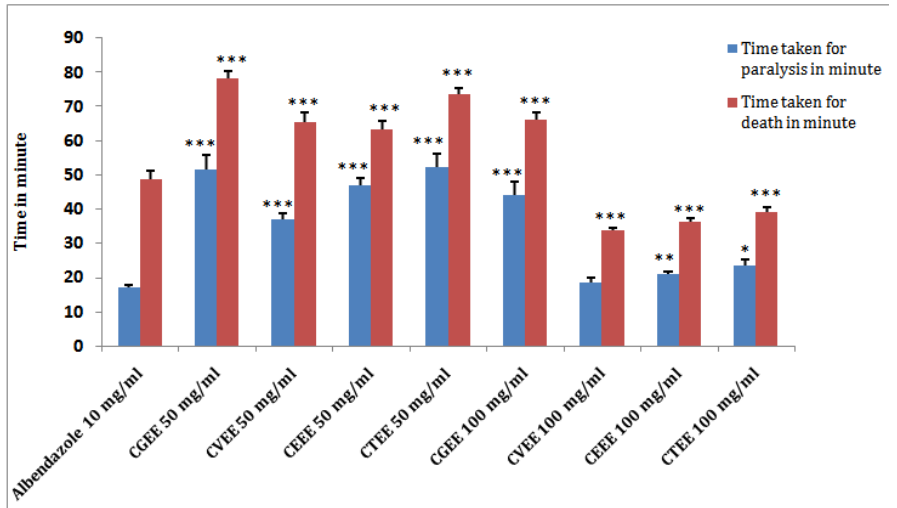

Figure 2 Anthelmintic activity of ethanol extract (leaf) of C. guruba, C. viminalis, C. erectus \& $C$. tenuis. 


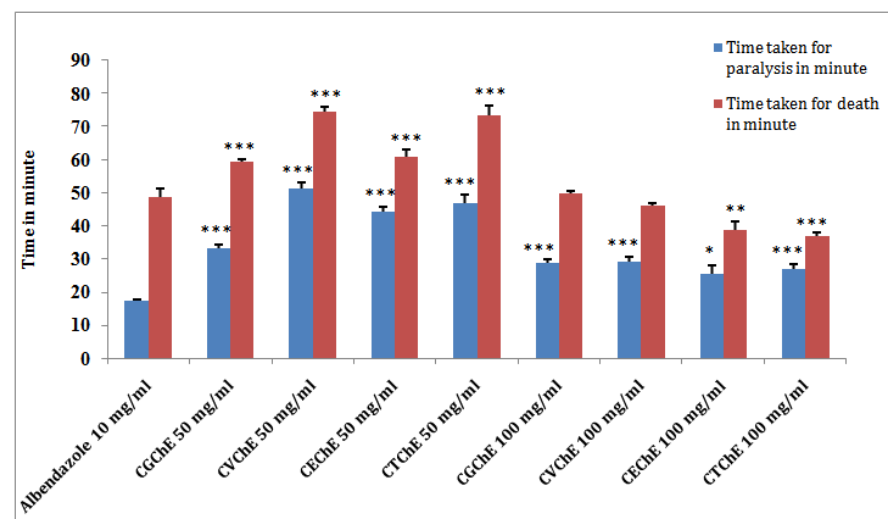

Figure 3 Anthelmintic activity of chloroform extract (leaf) of $C$. guruba, $C$. viminalis, $C$. erectus \& C. tenuis.

\section{Conclusion}

These findings suggest that methanol, ethanol, chloroform extracts of Calamus species have promising anthelmintic effects. We propose that future work should focus on attempting to identify the phytoconstituents for the isolation of pure compounds responsible for the specific biological action as demonstrated in this study.

\section{Acknowledgements}

None.

\section{Conflict of interest}

Author declares that there is no conflict of interest.

\section{References}

1. Hotez PJ, Brindley PJ, Bethony JM, et al. Helminth infections: the great neglected tropical diseases. J Clin Invest. 2008;118(4):1311-1321.

2. Hotez PJ, Molyneux DH, Fenwick A, et al. Incorporating a rapid-impact package for neglected tropical diseases with programs for HIV/AIDS, tuberculosis, and malaria. PLoS Med. 2006;3(5):e102.

3. Hotez PJ, Molyneux DH, Fenwick A, et al. Control of neglected tropical diseases. N Engl J Med. 2007;357(10):1018-1027.

4. Udavant PB, Satyanarayana SV, Upasani CD. In vitro anthelmintic activity of stems of Cuscuta reflexa. Int J Bioassays. 2012;1(8):18-19.

5. Patnaik M, Basak UC. Enzymatic antioxidant activities in eight wild edible fruits of Odisha. Trop plant Res. 2014;1(3):36-42.

6. Khandaker S, Das S, Opo FADM, et al. In vivo pharmacological investigations of the crude extracts of Calamus viminalis (L.). J Pharmacogn Phytochem. 2016;5(3):263-269.

7. Kitukale MD, Chandewar AV. An overview on some recent herbs having antidiabetic potential. Res J Pharm Biol Chem Sci. 2014;5(6):190-196.
8. Ahmed JU, Bithi SS, Khan MMR, et al. Phytochemical screening, antioxidant and cytotoxic activity of fruit extracts of Calamus tenuis Roxb. $J$ Coast Life Med. 2014;2(8):645-650.

9. Opo FADM, Das S, Khandokar S, et al. In vivo pharmacological investigations of leaf extracts of calamus tenuis Roxb. IJPRBS. 2016;5(4):1-12.

10. Tiwari P, Kumar B, Kaur M, et al. Phytochemical screening and extraction: a review. Int Pharm Sci. 2011;1:103-104.

11. Ajaiyeoba EO, Onocha PA, Olarenwaju OT. In vitro anthelmintic properties of Buchholzia coriacea and Gynandropsis gynandra extract. Pharm Biol. 2001;39(3):217-220.

12. Githiori JB, Höglund J, Waller PJ. Ethnoveterinary plant preparations as livestock dewormers: practices, popular beliefs, pitfalls and prospects for the future. Anim Health Res Rev. 2005;6(1):91-103.

13. Athanasiadou S, Githiori J, Kyriazakis I. Medicinal plants for helminth parasite control: facts and fiction. Animal. 2007;1(9):1392-1400.

14. Tolossa K, Debela E, Athanasiadou S, et al. Ethno-medicinal study of plants used for treatment of human and livestock ailments by traditional healers in South Omo, Southern Ethiopia. J Ethnobiol Ethnomed. 2013;9:1-15.

15. Pessoa LM, Morais SM, Bevilaqua CM, et al. Anthelmintic activity of Essential oil of Ocimum gratissimum Linn. and eugenol against Haemonchus contortus. Vet Parasitol. 2002;109(1-2):59-63.

16. Lahlou M. Potential of Origanum compactum as a cercaricide in Morocco. Ann Trop Med Parasitol. 2002;96:587-593.

17. Cowan MM. Plant Products as Antimicrobial Agents. Clin Microbiol Rev. 1999;12(4):564-582.

18. Mali RG, Mahajan SG, Mehta AA. In vitro Anthelmintic activity of stem bark of Mimusops elengi Linn. Phcog Mag. 2007;3(10):73-76.

19. Brunet S, Jackson F, Hoste H. Effects of sainfoin (Onobrychis viciifolia) extract and monomers of condensed tannins on the association of abomasal nematode larvae with fundic explants. Int $J$ Parasitol. 2008;38(7):783-790.

20. Novobilský A, Mueller-Harvey I, Thamsborg SM. Condensed tannins act against cattle nematodes. Vet Parasitol. 2011;182(2-4):213-220.

21. Williams AR, Fryganas C, Ramsay A, et al. Direct anthelmintic effects of condensed tannins from diverse plant sources against Ascaris suum. PLoS One. 2014;9(5):e97053.

22. Tandon V, Pal P, Roy B, et al. In vitro anthelmintic activity of root tuber extract of Flemingia vestita, an indigenous plant in Shillong, India. Parasitol Res. 1997;83(5):492-498.

23. Waller PJ, Bernes G, Thomsborg SM, et al. Plants as de-worming agents of livestock in Nordic countries: historical perspective,popular beliefs and prospects for the future. Acta Vet Scand. 2001;42(1):31-44.

24. Wang Y, Waghorn GC, Douglas GB, et al. The effect of condensed tannins in Lotus corniculatus upon nutrient metabolism and upon body and wool growth in grazing sheep. Proc New Zealand Soc of An Prod. 1994;54:219-222. 